\title{
Use of poultry pre-cooked slaughterhouse waste as ruminant feed to prevent environmental pollution
}

\author{
Mehdi Kazemi-Bonchenari ${ }^{\text {a }}$, AliReza Alizadeh ${ }^{\text {b, c }}$, Leila Javadi ${ }^{\text {b }}$, Mohammad Zohrevand ${ }^{\text {b }}$, \\ Nicholas E. Odongo ${ }^{\mathrm{d}}$, Abdelfattah Z.M. Salem ${ }^{\mathrm{e}, \text { * }}$ \\ a Department of Animal Science, Faculty of Agriculture and Natural Resources, Arak University, Arak, 38156-8-8349, Iran \\ b Department of Animal Science, Saveh Branch, Islamic Azad University, Saveh, Iran \\ c Department of Embryology, Reproductive Biomedicine Research Center, Royan Institute for Reproductive Biomedicine, ACECR, Tehran, Iran \\ d Department of Animal Sciences, School of Agriculture, Pwani University, P.O. Box 195-80108, Kilifi, Kenya \\ e Facultad de Medicina Veterinaria y Zootecnia, Universidad Autónoma del Estado de México, Mexico
}

\section{A R T I C L E I N F O}

\section{Article history:}

Received 11 June 2016

Received in revised form 7 January 2017

Accepted 11 January 2017

Available online 12 January 2017

\section{Keywords:}

Poultry slaughterhouse waste

Protein quality

Ruminant feedstuff

\begin{abstract}
A B S T R A C T
The generation of poultry slaughterhouse waste from poultry production is not only unavoidable but the amount and kinds of waste can cause environmental problems. In the present study, the potential rumen digestion of poultry slaughterhouse waste which consists of protein-rich organic residues was evaluated. The chemical composition, amino acid profile and Cornell Net Carbohydrate and Protein System fractions of these wastes was determined. Rumen digestion of poultry slaughterhouse waste was compared with two common protein sources (fish meal and roasted soybean). Three poultry slaughterhouse waste samples were collected from industrial poultry slaughter-houses and the in situ degradation was done using rumen cannulated sheep. The protein (50-63\%), ether extracts (18-27\%) and ash (9-15.5\%) contents of different poultry slaughterhouse waste samples were different $(\mathrm{P}<0.05)$. Methionine and lysine contents were similar among different poultry slaughterhouse waste sources. Difference were observed for cystine $(1.2-1.7 \%)$, threonine $(1.9-2.2 \%)$, arginine $(3-3.5 \%)$, leucine $(3.5-4.1 \%)$ and valine $(2.8-3.3 \%)$ $(\mathrm{P}<0.05)$. Ruminal degradation rate for dry matter, organic matter and protein were different among poultry slaughterhouse waste, fish meal and roasted soybean. The degradation parameter for protein degradation was $76 \%$ for poultry slaughterhouse waste, $79 \%$ for fish meal and $98 \%$ for roasted soybean $(\mathrm{P}<0.05)$. Results revealed that there was great variation in chemical composition, protein fractioning, and amino acid profiles of different poultry slaughterhouse waste sources. Poultry slaughterhouse waste is slowly-degraded protein in the rumen and thus can be an economical and rich source of rumen undegradable protein in ruminant nutrition. This implies that the use of poultry slaughterhouse waste in ruminant nutrition has a huge potential as a cleaner product of animal feeding and prevention environmental pollution. However, further studies are warranted to evaluate the digestibility of poultry slaughterhouse waste amino acids escaping the rumen into the intestine in ruminants and to compare the biological values for the amino acids in these waste material with common ruminant feedstuffs.
\end{abstract}

(C) 2017 Published by Elsevier Ltd.

\section{Introduction}

The waste products from the slaughter of poultry might be useful feedstuffs for protein supplementation in ruminant diets as a cleaner product for animal feeding while safeguarding the environment (Lallo and Garcia, 1994; Knaus et al., 1998). Yoon et al. (2014) reported that the amount of nitrogen obtainable from the slaughterhouse wastes was $22.4 \mathrm{~kg}$ per 1000 heads of poultry

Abbreviation: PSW, Poultry slaughterhouse waste; FM, fish meal; RSB, roasted soybean; CNCPS, Cornell net carbohydrate and protein system; DM, dry matter; CP, crude

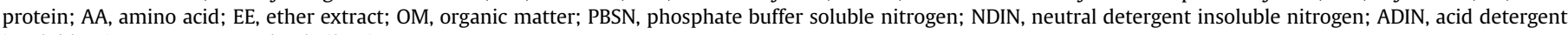
insoluble nitrogen; TVN, total volatile nitrogen.

* Corresponding author.

E-mail address: asalem70@yahoo.com (A.Z.M. Salem). 
which could be an excellent biological source of nitrogen (protein) in animal nutrition. However, the use and disposal of poultry slaughterhouse wastes (PSW) is difficult because it has not been adequate characterized biologically, its potential pathogenic contents and because of its high moisture and organic matter contents.

In Iran, the waste materials from poultry slaughterhouses is about 12.6 thousand tons per year (Geshlog-Olyayee et al., 2010). In addition to the different industrial uses of livestock wastes such as biogas production (Li et al., 2016) or electricity (Billen et al., 2015), including different waste materials from the livestock industries for evaluation in animal nutrition is a worthwhile endeavor. Some of the waste materials which have been evaluated in animal diets include bone and hydrolyzed feather meal in cattle (Knaus et al., 1998); meat and bone meal in steers (Klemesrud et al., 1998); poultry litter in Friesian steers (Muia et al., 2001), slaughter-house blood in steers (Ayangbile et al., 1993) and feather meal in juvenile tench diets (González-Rodríguez et al., 2014).

Among the different animal waste materials, PSW is one of the most important rendering by-product with a high protein content for use to feed ruminants (Meeker and Hamilton, 2006). Klemesrud et al. (1998) evaluated the protein efficiency of numerous sources of PSW in growing steers and found that the protein efficiency of PSW was greater than that of meat and bone meal. Similarly, Lallo and Garcia (1994) reported that including PSW as protein substitute for soybean meal (i.e., SBM) could decrease feed costs in growing hair lambs. However, a better understanding of the chemical composition and protein degradation patterns of PSW would be very useful in improving the accuracy of formulation of animal diet (Kamalak et al., 2005; González-Rodríguez et al., 2014).

It is well known that the disappearance of feed protein in the rumen is an important aspect in ruminant nutrition in different ruminant feed evaluation systems (AFRC, 1993; NRC, 2001). Although some feeding trials have been conducted with inclusion of PSW in animal diets as previously reviewed by Jayathilakan et al. (2012), there is still insufficient information on the chemical composition, nitrogen solubility, protein fractions, and amino acid profile of this by-product. Furthermore, the comparison of PSW degradation in the rumen with common protein sources in animal nutrition is not well documented. Consequently, evaluation the chemical composition of these waste materials as well as their nutritional value would increase their use in the animal nutrition industry and reduce their negative effects on environment. In the present study, the chemical composition, protein fractionation based on Cornell Net Carbohydrate and Protein System (CNCPS), and amino acid contents of different sources of PSW were evaluated. Additionally, rumen degradation rate of PSW was compared with that of fish meal and roasted soybean to evaluate the potential of substituting common feedstuffs with this by-product in ruminant nutrition.

\section{Materials and methods}

\subsection{Samples preparation}

The PSW samples were obtained from three slaughter-houses from Tehran province, Tehran, Iran (Teyhoo; S1, Kooshan; S2 and Makian; S3) ( $\left.35^{\circ} 41^{\prime} \mathrm{N} 51^{\circ} 20^{\prime} \mathrm{E}\right)$. Nine sub-samples were collected from each slaughter-house. The samples contained all waste materials such as blood, necks, feathers, skin and bones. However, the gastrointestinal organs were not included in the samples to avoid contamination and because of disease infection concerns. The above mentioned parts were cooked to produce PSW at a relatively high boiling temperature of $90 \mathrm{C}^{\circ}$.

The samples were then evaluated for total volatile nitrogen (TVN) and total bacterial count (TBC). For the determination of TVN,
$10 \mathrm{~g}$ of each sample was obtained and placed in the Kjeldahl distillation system and volatile nitrogen collected in a glass balloon containing boric acid 2\%, methyl red and bromocresol green and consequently titrated with sulfuric acid $(0.1 \mathrm{~N})$ for the measurement of TVN (mg $100 \mathrm{~g}^{-1}$ of sample) (AOAC, 1992). The TBC was determined as described by Karaboz and Dincer (2006). The dry matter (DM) of the samples was determined by oven drying at $50-55{ }^{\circ} \mathrm{C}$ for $48 \mathrm{~h}$ (AOAC, 1990) and the dry samples stored for further chemical analysis.

\subsection{Chemical analysis}

The nine samples from each slaughterhouse were pooled and sub-sampled to make three samples per slaughterhouse. Dried PSW samples were ground through a $1 \mathrm{~mm}$ screen (Wiley mill, Arthur H. Thomas, Philadelphia, PA), and samples analyzed for amino acids, total nitrogen, fat, ash and organic matter (AOAC, 1990). The CNCPS protein fractions of the PSW was determined according to standardized procedure of Licitra et al. (1996) at the University of Bahonar, Kerman. The $\mathrm{B}_{2}$ fraction was calculated by difference and results are reported as $\mathrm{CP}$ percentage. Phosphate buffer soluble nitrogen (PBSN) was determined using the phosphate buffer. Neutral detergent insoluble nitrogen (NDIN) and acid detergent insoluble nitrogen (ADIN) were determined as the nitrogen content of the residual after neutral and acid detergent procedures. The analysis of 11 amino acids i.e. arginine, cysteine, histidine, isoleucine, leucine, lysine, methionine, phenylalanine, threonine, tryptophan and valine in three different PSW samples was performed using NIRS, FOSS 5000 Denmark at the Paya Amin Mehr Company (Tehran, Iran).

\subsection{In situ experiment}

Samples of PSW from three slaughterhouses was used in the in situ experiment. The ruminal degradation of nutrients in PSW was compared with fish meal (FM) and roasted soybean (RSB). The in situ experiment was conducted at Azad University (Tabriz branch), animal station center, Iran. Three rumen-cannulated male Ghezel sheep averaging BW $35 \pm 2.5 \mathrm{~kg}$ were used in a $3 \times 3$ Latin square design experiment. The basal diet consisted of $50 \%$ alfalfa hay and the rest was concentrate which consisted of 35\% barley plus $15 \%$ of equal mixture of three experimental treatments (i.e., FM, RSB and PSW). The animals were kept in individual cages and had free access to water. The animals were fed twice daily at 08:00 and 14:00 $\mathrm{h}$. The samples were ground to pass through a $2 \mathrm{~mm}$ screen size (Wiley mill, Arthur H. Thomas, Philadelphia, PA). $3.5 \mathrm{~g}$ of samples was weighed into nylon bags with $45 \mu \mathrm{m}$ pore size and the bags labeled with a waterproof permanent marker. Triplicate samples were incubating for $0,4,8,16,24,36$ and $48 \mathrm{~h}$, before morning feeding. After incubation, bags were removed from the rumen and rinsed with cold tap water, until the rinse water remained clear. The bags were then dried at $55{ }^{\circ} \mathrm{C}$ for $48 \mathrm{~h}$ in a forced air oven and then weighed. Aliquots of the residuals in the bags were used for DM, OM and $\mathrm{CP}$ determination. The degradation profiles were calculated by the nonlinear model described by Ørskov and McDonald (1979). The effective degradability (ED) in the rumen was calculated as, $E D=a+[(b \times c) /(c+k)]$, using the NEWAY software, where "a" is the water-soluble fraction, "b" the potentially degradable fraction, " $c$ " the rate of degradation of "b", and " $k$ " the passage rate of the digesta out of the rumen. Different ED values were measured at different passage rates of $\mathrm{k}=0.02,0.05$ and 0.08 . The chemical analysis (\%) of the PSW sample used in the in situ experiment was as follow; $\mathrm{OM}=88.5, \mathrm{CP}=56.2, \mathrm{EE}=20.5$ and ash $=10.8$. The OM contents (\%) of FM and RSB were 91.3 and 94.5, CP contents of FM and RSB were 68.9 and 38.1, and EE contents 
of FM and RSB were 5.6 and 4.3.

\subsection{Statistical analysis}

Data collected in different chemical analyses was analyzed using Proc GLM in SAS (2000) (version 8.1; SAS institute Inc., Cary, NC). The following model was fitted to variables;

$Y_{i}=\mu+T_{i}+\varepsilon_{i}$

where $Y_{i}$ is the dependent variable, $\mu$ is the overall mean, $T_{i}$ is the effect of treatmenti, and $\varepsilon_{i}$ is the residual error.

Data from the in situ experiment was analyzed using Proc. GLM in SAS. The following model was fitted to variables;

$Y_{i j k}=\mu+P_{i}+S_{j}+T_{k}+\varepsilon_{i j k}$

where $Y_{i j k}$ is the dependent variable, $\mu$ is the overall mean, $P_{i}$ is the effect of period $i, S_{j}$ is the effect of sheep $j, T_{k}$ is the effect of treatment $k$, and $\varepsilon_{i j k}$ is the residual error.

\section{Results}

\subsection{Chemical composition and CNCPS fractions}

Total bacterial count averaged $3 \times 10^{4} \mathrm{CFU} / \mathrm{g}$ and total volatile nitrogen (i.e., TVN) averaged $167.4 \mathrm{mg} / 100 \mathrm{~g}$ nitrogen in PSW samples. There were no differences $(P>0.05)$ among treatments in these two parameters (Table 1 ). The OM content of samples were also similar $(\mathrm{P}>0.05)$ among PSW sources. However, $\mathrm{CP}$ and ash contents were significant difference $(P<0.05)$ among PSW samples. The EE contents for S1 and S2 were similar but these were less than EE content in S3 $(\mathrm{P}<0.05)$. The phosphate buffer soluble nitrogen (PSBN) content was also similar between S1 and S2 but both were greater than that of $\mathrm{S} 3(\mathrm{P}<0.05)$. Neutral detergent insoluble nitrogen (NDIN) and acid detergent insoluble nitrogen (ADIN) contents in S1 had the lowest values among different PSW sources $(\mathrm{P}<0.05)$. The greatest value for NDIN was $8.64 \%$ observed for $\mathrm{S} 2$. The CNCPS fractions of $A$ and $B_{2}$ were similar among different PSW samples. However, $\mathrm{B}_{3}$ fraction was lower in $\mathrm{S} 1$ sample compared to S2 and S3 samples. However, $B_{1}$, and $C$ fractions were different among PSW sources $(\mathrm{P}<0.05)$. The greatest amount for fraction $\mathrm{C}$ was $3.4 \%$ which was observed in S2 (Table 2).

\subsection{Amino acid profile}

Regarding the AA composition, the profile of arginine, cysteine, leucine, threonine and valine were similar between S1 and S3, but these were greater $(\mathrm{P}<0.05)$ than those in $\mathrm{S} 2$ sample (see Table 3 ).

Table 1

Chemical composition of different poultry slaughterhouse waste samples (\% of DM) ( $\mathrm{n}=9$ subsamples/slaughterhouse).

\begin{tabular}{lllllll}
\hline & \multicolumn{3}{l}{ PSW samples $^{1}$} & \multirow{2}{*}{ SE } & P-value \\
\cline { 2 - 4 } & S1 & S2 & S3 & & \\
\hline Organic matter & 84.5 & 88.8 & 90.9 & 3.76 & N.S. \\
Ether extract & $18.0^{\mathrm{b}}$ & $18.3^{\mathrm{b}}$ & $27.9^{\mathrm{a}}$ & 1.07 & $*$ \\
Crude protein & $55.6^{\mathrm{b}}$ & $62.7^{\mathrm{a}}$ & $50.7^{\mathrm{c}}$ & 2.19 & $*$ \\
Ash & $15.5^{\mathrm{a}}$ & $11.2^{\mathrm{b}}$ & $9.14^{\mathrm{c}}$ & 0.97 & $*$ \\
Total volatile nitrogen, $\mathrm{mg} / 100 \mathrm{~g}$ DM & 162 & 167 & 174 & 2.9 & N.S. \\
Total bacterial count $\times 10^{4}$, CFU/g & 2.9 & 3.1 & 3.0 & 0.1 & N.S. \\
\hline
\end{tabular}

${ }^{1}$ Different PSW samples which were supplied from different slaughter-houses were $\mathrm{S} 1=$ Teyhoo: $\mathrm{S} 2=$ Kooshan and S3 = Makian.

Means in the same row with different superscripts differ $(\mathrm{P}<0.05)$.

${ }^{2}$ P-value; N.S.; non-significant; *; Significant at $\mathrm{P}<0.05$; ${ }^{* *}$; Significant at $\mathrm{P}<0.01$.
Table 2

Nitrogen solubility and protein fractions based on CNCPS for different poultry slaughterhouse waste sources ( $\mathrm{n}=3$ subsamples/slaughterhouse).

\begin{tabular}{|c|c|c|c|c|c|}
\hline & \multicolumn{3}{|c|}{ PSW samples $^{1}$} & \multirow[t]{2}{*}{ SE } & \multirow[t]{2}{*}{ P-value ${ }^{4}$} \\
\hline & S1 & S2 & S3 & & \\
\hline \multicolumn{6}{|c|}{ Nitrogen solubility ${ }^{2}(\%)$} \\
\hline PBSN & $16.81^{\mathrm{a}}$ & $15.12^{\mathrm{ab}}$ & $12.44^{\mathrm{b}}$ & 0.54 & $*$ \\
\hline NDIN & $5.65^{c}$ & $8.64^{\mathrm{a}}$ & $7.22^{\mathrm{b}}$ & 0.11 & $*$ \\
\hline ADIN & $1.09^{\mathrm{c}}$ & $2.54^{\mathrm{a}}$ & $2.04^{\mathrm{b}}$ & 0.08 & $*$ \\
\hline \multicolumn{6}{|c|}{ CNCPS fractioning $^{3}$ (\% of CP) } \\
\hline A & 4.21 & 6.18 & 4.92 & 0.12 & N.S. \\
\hline $\mathrm{B}_{1}$ & $22.11^{\mathrm{a}}$ & $13.98^{\mathrm{c}}$ & $15.49^{\mathrm{b}}$ & 0.24 & $* *$ \\
\hline $\mathrm{B}_{2}$ & 64.82 & 68.3 & 67.72 & 2.38 & N.S. \\
\hline $\mathrm{B}_{3}$ & $7.14^{\mathrm{b}}$ & $8.12^{\mathrm{a}}$ & $8.51^{\mathrm{a}}$ & 0.26 & $*$ \\
\hline $\mathrm{C}$ & $1.70^{\mathrm{c}}$ & $3.40^{\mathrm{a}}$ & $3.33^{\mathrm{b}}$ & 0.09 & $*$ \\
\hline
\end{tabular}

${ }^{1}$ Different PSW samples which were supplied from different slaughter-houses were; $\mathrm{S} 1=$ Teyhoo; S2= Kooshan and S3 = Makian

${ }^{2}$ PBSN = Phosphate buffer soluble nitrogen; NDIN = Neutral detergent insoluble nitrogen; ADIN = Acid detergent insoluble nitrogen.

${ }^{3} \mathrm{CNCPS}$ fractioning parameters; fraction A: soluble in buffer and trichloracetic acid, fraction $\mathrm{B}_{1}$ : soluble in buffer and precipitated by trichloracetic acid, fraction $\mathrm{B}_{2}$ : insoluble in buffer but soluble in neutral detergent, fraction $\mathrm{B}_{3}$ : soluble in acid detergent but insoluble in neutral detergent, fraction C: insoluble in acid detergent. Means in the same row with different superscripts differ $(P<0.05)$.

${ }^{4}$ P-value; N.S.; non-significant; *; Significant at $\mathrm{P}<0.05$; ${ }^{* *}$; Significant at $\mathrm{P}<0.01$.

Table 3

Amino acid profiles for different poultry slaughterhouse waste samples (expressed as percent in $91 \%$ DM) $(\mathrm{n}=3$ subsamples/slaughterhouse).

\begin{tabular}{llllll}
\hline & \multicolumn{2}{l}{ PSW samples ${ }^{1}$} & & SE & \multirow{2}{*}{ P-value $^{3}$} \\
\cline { 2 - 4 } & S1 & S2 & S3 & & \\
\hline Arginine & $3.537^{\mathrm{a}}$ & $2.980^{\mathrm{b}}$ & $3.348^{\mathrm{ab}}$ & $0.151-$ & $*$ \\
Cysteine & $1.629^{\mathrm{ab}}$ & $1.236^{\mathrm{b}}$ & $1.772^{\mathrm{a}}$ & 0.062 & $*$ \\
Histidine & 0.871 & 0.981 & 0.999 & 0.084 & N.S. \\
Isoleucine & 2.138 & 1.834 & 2.226 & 0.101 & N.S. \\
Leucine & $3.941^{\mathrm{ab}}$ & $3.497^{\mathrm{b}}$ & $4.136^{\mathrm{a}}$ & 0.203 & $*$ \\
Lysine & 1.935 & 2.176 & 2.204 & 0.102 & N.S. \\
Methionine & 0.566 & 0.639 & 0.667 & 0.024 & N.S. \\
Phenylalanine & 2.374 & 2.075 & 2.413 & 0.133 & N.S. \\
Threonine & $2.163^{\mathrm{a}}$ & $1.899^{\mathrm{b}}$ & $2.264^{\mathrm{a}}$ & 0.141 & $*$ \\
Tryptophan & 0.423 & 0.438 & 0.482 & 0.181 & N.S. \\
Valine & $3.249^{\mathrm{a}}$ & $2.794^{\mathrm{b}}$ & $3.342^{\mathrm{a}}$ & 0.210 & $*$ \\
TSAA $^{2}$ & $2.156^{\mathrm{ab}}$ & $1.784^{\mathrm{b}}$ & $2.382^{\mathrm{a}}$ & 0.130 & $*$ \\
\hline
\end{tabular}

Mean in the same row with different letters differ $(P<0.05)$.

${ }^{1}$ Different PSW samples which were supplied from different slaughter-houses were; $\mathrm{S} 1=$ Teyhoo; $\mathrm{S} 2=$ Kooshan and S3 = Makian.

${ }^{2}$ TSAA; Total sulfur amino acids (methionine + cystine).

Means in the same row with different superscripts differ $(P<0.05)$.

${ }^{3}$ P-value; N.S.; non-significant; *; Significant at $\mathrm{P}<0.05$; ${ }^{* *}$; Significant at $\mathrm{P}<0.01$.

In contrast, histidine, isoleucine, lysine, methionine, phenylalanine and tryptophan contents of different PSW samples were similar in this study $(P>0.05)$. The arginine content was similar between $\mathrm{S} 1$ and S3, however it was lower by about $18.5 \%$ between S1 and S2 samples. Total sulfur amino acid (methionine + cysteine) content was similar between S1 and S3 but these were different from S2 sample mainly due to the different cysteine levels.

\subsection{In situ ruminal degradability of $D M, O M$ and $C P$}

The kinetics of "a" and "b" parameters were different among treatments for measured nutrients i.e. DM, OM and CP (Table 4). Rapidly degradable protein fraction (a) for DM was lower for PSW compared to FM and RSB which were similar. However, this fraction for OM was different among treatments. Slowly degradable fraction (b) for DM was lower for PSW compared to FM and RSB which were similar and for OM degradation, the (b) fraction for PSW was similar to FM and FM similar to RSB but RSB was greater than PSW. 
Table 4

In situ degradation kinetics of nutrients of poultry slaughterhouse waste, fish meal and roasted soybean.

\begin{tabular}{|c|c|c|c|c|c|c|c|c|}
\hline & \multicolumn{5}{|c|}{ Kinetics parameters ${ }^{1}$} & \multicolumn{3}{|c|}{ Effective degradability (\%) } \\
\hline & & $\mathrm{a}(\%)$ & $\mathrm{b}(\%)$ & $a+b(\%)$ & $c^{(h-1)}$ & $\mathrm{K}=0.02$ & $\mathrm{~K}=0.05$ & $\mathrm{~K}=0.08$ \\
\hline \multirow[t]{5}{*}{ DM } & $\mathrm{PSW}^{2}$ & $13.1^{\mathrm{b}}$ & $52.5^{\mathrm{b}}$ & $65.6^{\mathrm{b}}$ & $0.038^{\mathrm{b}}$ & $59.8^{\mathrm{b}}$ & $55.4^{\mathrm{b}}$ & $53.6^{\mathrm{b}}$ \\
\hline & FM & $18.3^{\mathrm{a}}$ & $75.4^{\mathrm{a}}$ & $93.6^{\mathrm{a}}$ & $0.046^{\mathrm{ab}}$ & $78.8^{\mathrm{a}}$ & $75.3^{\mathrm{a}}$ & $68.2^{\mathrm{a}}$ \\
\hline & RSB & $18.2^{\mathrm{a}}$ & $79.7^{\mathrm{a}}$ & $98.1^{\mathrm{a}}$ & $0.053^{\mathrm{a}}$ & $76.5^{\mathrm{a}}$ & $74.5^{\mathrm{a}}$ & $69.6^{\mathrm{a}}$ \\
\hline & SE & 0.12 & 0.87 & 1.09 & 0.002 & 1.18 & 1.34 & 1.52 \\
\hline & P-value ${ }^{3}$ & $*$ & $* *$ & $* *$ & $*$ & $* *$ & $*$ & $*$ \\
\hline \multirow[t]{5}{*}{ OM } & PSW & $11.2^{c}$ & $55.6^{\mathrm{b}}$ & $66.6^{\mathrm{b}}$ & $0.029^{c}$ & $61.1^{\mathrm{c}}$ & $57.3^{c}$ & $56.5^{c}$ \\
\hline & FM & $18.3^{\mathrm{a}}$ & $74.7^{\mathrm{ab}}$ & $92.8^{\mathrm{ab}}$ & $0.047^{\mathrm{b}}$ & $84.3^{\mathrm{b}}$ & $80.5^{b}$ & $76.8^{\mathrm{b}}$ \\
\hline & RSB & $16.3^{\mathrm{b}}$ & $82.5^{\mathrm{a}}$ & $97.5^{\mathrm{a}}$ & $0.052^{\mathrm{a}}$ & $90.1^{\mathrm{a}}$ & $87.4^{\mathrm{a}}$ & $82.3^{\mathrm{a}}$ \\
\hline & SE & 0.76 & 2.46 & 2.67 & 0.006 & 2.97 & 2.34 & 2.11 \\
\hline & $P$-value ${ }^{3}$ & $*$ & $* *$ & $* *$ & $*$ & $* *$ & $* *$ & $* *$ \\
\hline \multirow[t]{5}{*}{$\mathrm{CP}$} & PSW & $28.2^{\mathrm{a}}$ & $48.6^{c}$ & $76.6^{c}$ & 0.047 & $63.3^{c}$ & $58.9^{c}$ & $52.3^{c}$ \\
\hline & FM & $26.1^{\mathrm{ab}}$ & $53.2^{\mathrm{b}}$ & $79.2^{\mathrm{b}}$ & 0.052 & $73.3^{\mathrm{b}}$ & $69.2^{\mathrm{b}}$ & $59.3^{\mathrm{b}}$ \\
\hline & RSB & $25.1^{\mathrm{b}}$ & $73.2^{\mathrm{a}}$ & $98.6^{\mathrm{a}}$ & 0.058 & $81.8^{a}$ & $78.5^{\mathrm{a}}$ & $68.9^{\mathrm{a}}$ \\
\hline & SE & 0.69 & 2.06 & 3.18 & 0.002 & 2.27 & 2.90 & 2.43 \\
\hline & $P$-value ${ }^{3}$ & $*$ & $* *$ & $* *$ & N.S. & $* *$ & $* *$ & $*$ \\
\hline
\end{tabular}

${ }^{1}$ Treatments were; PSW = poultry slaughterhouse waste, $\mathrm{FM}=$ fish meal, $\mathrm{RSB}=$ roasted soybean.

${ }^{2} a$, rapidly degradable fraction; $b$, slowly degradable fraction; $c$, rate constant of degradation of $b$ fraction.

Means in the same column with different superscripts differ $(\mathrm{P}<0.05)$.

${ }^{3}$ P-value; N.S.; non-significant; *; Significant at $\mathrm{P}<0.05$; **; Significant at $\mathrm{P}<0.01$.

Regarding the CP degradation, the lowest and the greatest (b) parameter was for PSW and RSB, respectively. A similar pattern for $(\mathrm{a}+\mathrm{b})$ was obtained regarding the $\mathrm{CP}$ degradation. However, $(\mathrm{a}+\mathrm{b})$ for DM and OM degradation were similar between FM and RSB and were greater than those of PSW treatment. The parameter $(a+b)$ which is potentially degradable fraction of protein, was $76 \%$ for PSW versus $79 \%$ for FM and $98 \%$ for RSB. Degradation coefficients (c) were similar for $\mathrm{CP}$ degradation among treatments, however, it was different among treatment for OM degradation. Effective degradability in all measured passage rates (i.e. $\mathrm{K}=2,5,8 \%$ ) were different among treatments for $\mathrm{OM}$ and $\mathrm{CP}$ degradation. The effective degradability for DM degradation was similar between RSB and FM which were greater than those of PSW.

\section{Discussion}

\subsection{Chemical analysis of PSW samples}

The chemical analysis of PSW samples in the present study clarified that the range of CP was about $50-63 \%$. Work on poultry by-product samples supplied in poultry slaughter-houses in Turkey indicated that PSW contained 55\% CP, 13.8\% EE and 16\% ash (Kamalak et al., 2005). Variation in EE contents were also observed for different samples in the current study. The variation of EE content in poultry offal affected metabolizable energy calculated by Dale et al. (1993) where the higher EE content caused to greater ME content in by-product. Therefore, it seems that to prevent under- or over estimation of energy or protein values of dietary materials included in PSW, its chemical analysis is necessary. Because of relatively high fat content in some PSW sample parts, this would increase energy content of this feedstuff. Rojas and Stein (2013) compared PSW and soybean meal energy content and reported greater metabolizable energy of PSW (4585 kcal/kg DM) compared to soybean meal energy content (4091 kcal/ $\mathrm{kg} \mathrm{DM}$ ). Because these waste materials have previously been used in biomass energy production (Li et al., 2016), their variations in energy content may also influence the energy level. Both the TVN and TBC (which shows the quality of the by-product) were similar among the three PSW samples. Because the slaughtering process as well as cooking process to prepare PWS were similar in three slaughterhouses these were expected to have similar microbial condition.

Loerch et al. (1983) reported an ADIN content of 4.6\% in total nitrogen content for soybean meal vs. $10 \%$ for meat and bone meal. In the current study the fractions B1 and C in CNCPS analysis showed differences among PSW samples. The greatest variation among PSW samples was found for fraction $\mathrm{B}_{1}$ which was about 8.1\%. Previous work showed that different ratios of fractions in protein sources could influence ruminal degradation rate (Kim and Patterson, 2003), so because of high variation found for PSW in the present study more research in needed to evaluate its ruminal degradation.

The AA contents of PSW samples from different slaughterhouse were different. In the present study, the contents of 11 amino acids was assessed and the results indicated that five out of the $11 \mathrm{AA}$ were different among different samples of PSW. The chemical composition of common feedstuffs (FM and RSB) in animal nutrition were evaluated in previous work and was compared with PSW. Knaus et al. (1998) compared AA composition of feather meal with FM and soybean meal. They found a relative increment for arginine, leucine, threonine, and valine in feather meal. On the other hand, in their study lysine content of feather meal was lower compared to FM and SBM. In the current study, methionine content of different PSW samples were relatively low in comparison with FM and SBM. In agreement with the present results, Klemesrud et al. (1997) indicated that the biological value of protein in PSW was limited by the amount of metabolizable methionine it contained. In contrast, Klemesrud et al. (1998) stated that neither methionine nor lysine was the first limiting amino acid when PSW was fed to growing cattle. Johnson et al. (1998) reported that the contents of arginine $(=4.65 \%)$, histidine $(=1.24 \%)$, isoleucine $(=2.3 \%)$, leucine $(=4.44 \%)$, lysine $(=3.58 \%)$, methionine $(=1.2 \%)$, phenylalanine $(=2.25 \%)$, threonine $(=2.56 \%)$ and valine $(=2.94 \%)$ in PSW samples. Because of high variation found in chemical composition of different PSW samples, the present study indicates that PSW quality as feedstuff in animal nutrition could be different from batch to batch.

\subsection{In situ ruminal degradability}

Regarding the degradation profiles, $(\mathrm{a}+\mathrm{b})$ parameter was lowest for CP degradation for PSW in comparison to FM and RSB. In addition, parameter (b) was lowest for PSW compared to other treatments. This suggest that PSW has slower trend of protein than that of FM and RSB in sheep rumen. Including PSW in steer diet, 
Bohnert et al. (1998) reported that nitrogen disappearance in rumen for PSW was $1.4 \%$ vs. $12.8 \%$ per hour for soybean meal. They indicated that the ruminal escape amount of PSW nitrogen was about 55\% vs. 25\% for soybean meal. Kim and Patterson (2003) showed that treating hen mortality meal with $\mathrm{NaOH}$ or enzyme caused faster degradation of protein in rumen of dairy cows and consequently greater availability of amino acids for rumen microorganisms compared to un-treated hen mortality meal. Because of the lower $(\mathrm{a}+\mathrm{b})$ content of protein of PSW in comparison with FM and RSB, these results show that greater content of protein in PSW has potential to escape from the rumen degradation. Klemesrud et al. (1997) reported that escape protein values in steers, determined by 12 -h in situ incubation, ranged from 32 to $40 \%$ of CP for PSW. Moreover, Kamalak et al. (2005) reported that animal-derived protein sources such as PSW with a low degradability can be used to increase by-pass protein. The present study indicated that PSW contained greater amount of slowly-degradable protein compared with FM and RSB. Although the entrance of AA into the small intestine was not measured, supplementing diets with proteins that are resistant to ruminal degradation can increase the amount and (or) alter the pattern of amino acids entering the small intestine and increase nitrogen retention (Cecava and Hancock, 1994). Knaus et al. (1998) suggested that bone meal and hydrolyzed feather meal could be considered as un-degraded intake protein sources that could improve nitrogen digestibility, nitrogen balance, and efficiency of nitrogen utilization in growing-finishing cattle. The PSW was shown to have a slow degradation of DM, OM and CP in the present study in comparison with the other two tested feedstuffs. High fat content in PSW which was found in the present study (equal to 20.5\%) might be one of the presumed reasons. High fat content in PSW has been shown to cause the "coating theory" in rumen as was explained by Devendra and Lewis (1974). In this theory, protein degradation and microbial access to feed protein would be decreased because of the covering effect of fat on protein in feed. High amounts of some amino acids such as cystine, glutamic acid and proline in such products would also cause slow degradation of protein in rumen as described by Kim and Patterson (2003). It was suggested that these AA could create rigidity in protein structure which would cause slower ruminal degradation. In the present study, slower protein degradation trend for PSW $(\mathrm{a}+\mathrm{b})$ compared to common protein sources (i.e. FM and RSB, Table 4) emphasis that this product has potential to be used as slow-degradation protein source in ruminant nutrition. Ruminants require sufficient protein in the diet to optimize microbial growth in the rumen, and adequate amounts of essential amino acid to be available in the small intestine for their increased metabolic demands (Casper et al., 1999; NRC, 2001). The presents study revealed that PSW could be consider as relatively resistance to microbial degradation in rumen and consequently has potential to increase rumen escapable protein compared to FM and RSB in ruminant nutrition. In fact, PSW could present some amino acids directly into the small intestine of ruminant animal. However, further research is warranted on the digestibility of this waste material.

\section{Conclusion}

Poultry slaughterhouse waste could be consider as a slowlydegraded protein in the rumen and thus an economical and rich source of rumen un-degradable protein in ruminant nutrition. This implies that poultry slaughterhouse waste has a huge potential as a cleaner product for animal feeding while safeguarding the environment. However, further studies are warranted to evaluate the digestibility of PSW amino acids escaping the rumen into the intestine in ruminants and to compare the biological values for the AAs in this waste material with common feedstuffs.

\section{Conflict of interest}

The authors declare that there is no conflict of interest regarding the publication of this paper.

\section{Acknowledgments}

The authors are thankful to the sheep unit crew for keeping the rumen cannulated-sheep and helping in sampling. They also express their regards to $\mathrm{Mr} \mathrm{E}$. Mohammadi-Koutiany and $\mathrm{Mr}$. $\mathrm{H}$. Tahami for supplying the poultry slaughterhouse waste samples. The assistance by Paya Amin Mehr Company (Tehran, Iran) and Mrs. G. Khakranfor in analyzing amino acid content of feed is appreciated. The partly financial support by Islamic Azad University (AzaUni-1391) (IZU; Saveh Branch) is appreciated as well. Finally, great appreciation for roasted soybean meal donated by Mr. Amin Akbarian.

\section{References}

AFRC, 1993. Energy and protein requirements of ruminants. In: An Advisory Manual Prepared by the AFRC Technical Committee on Response to Nutrients. CAB International, Wallingford, UK (compiled by G. Alderman, in collaboration with B.R. Cottrill).

AOAC, Association of Official Analytical Chemists, 1990. Official Methods of Analysis, fifteenth ed. AOAC, Washington, DC, USA.

AOAC, 1992. Official Methods of Analysis, fifteenth ed. Association of Official Analytical Chemists Inc., Arlington, VA, USA.

Ayangbile, O.A., Tallam, S.K., Surtan, M.S., 1993. Processing of slaughterhouse blood and poultry litter and the effects on nutrient digestibility by steers. Anim. Feed. Sci. Technol. 40, 153-164.

Billen, P., Costa, J., Van der Aa, L., Van Caneghaem, J., Vandecasteele, C., 2015. Electricity from poultry manure: a cleaner alternative to direct land application. J. Clean. Prod. 96, 467-475.

Bohnert, D.W., Larson, B.T., Bauer, M.L., Branco, A.F., McLeod, K.R., Harmon, D.L., Mitchell Jr., G.E., 1998. Nutritional evaluation of poultry by-product meal as a protein source for ruminants: effects on performance and nutrient flow and disappearance in steers. J. Anim. Sci. 76, 2474-2484.

Casper, D.P., Maiga, H.A., Brouk, M.J., Schingoethe, D.J., 1999. Synchronization of carbohydrate and protein sources of fermentation and passage rates in dairy cows. J. Dairy Sci. 82, 1779-1790.

Cecava, M.J., Hancock, D.L., 1994. Effects of anabolic steroids on nitrogen metabolism and growth of steers fed corn silage and corn-based diets supplemented with urea or combinations of soybean meal and feather meal. J. Anim. Sci. 72, 515-522.

Dale, N., Fancher, B., Zumbado, M., Villacres, A., 1993. Metabolizable energy content of poultry offal meal. J. Appl. Poult. Res. 2, 40-42.

Devendra, C., Lewis, D., 1974. The interaction between dietary lipids and fiber in the sheep. Anim. Prod. 19, 67.

Geshlog-Olyayee, M., Janmohammadi, H., Taghizadeh, A., Rafat, S.A., 2010. Effects of poultry by-product meal on performance, egg quality and blood parameters of commercial laying hens in the 42-54 weeks of age. Iran. Anim. Sci. Res. J. 21, 29-42. In Persian.

González-Rodríguez, Á., Celada, J.D., Carral, J.M., Sáez-Royuela, M., Fuertes, J.B., 2014. Evaluation of a practical diet for juvenile tench (Tincatinca L.) and substitution possibilities of fish meal by feather meal. Anim. Feed. Sci. Technol. 187, 61-67.

Jayathilakan, K., Sultana, K., Radhakrishna, K., Bawa, A.S., 2012. Utilization of byproducts and waste materials from meat poultry and fish processing industries: a review. J. Food Sci. Technol. 49 (3), 278-293.

Johnson, M.L., Parsons, C.M., Fahey Jr., G.C., Merchen, N.R., Aldrich, C.G., 1998. Effects of species raw material source, ash content and processing temperature on amino acid digestibility of animal by-product meals by cecectomized roosters and ileally cannulated dogs. J. Anim. Sci. 76, 1112-1122.

Kamalak, A., Canbolat, O., Gurbuz, Y., Ozay, O., 2005. In situ ruminal dry matter and crude protein degradability of plant- and animal- derived protein sources in Southern Turkey. Small Rumin. Res. 58, 135-141.

Karaboz, I., Dincer, B., 2006. Microbiological investigations on some of the commercial frozen meat in Izmir. Turk. Electron. J. Biotech. 18, 23. Special issue.

Kim, W.K., Patterson, P.H., 2003. In situ evaluation of hen mortality meal as a protein supplement for dairy cows. J. Dairy Sci. 86, 3372-3342.

Klemesrud, M.J., Klopfenstein, T.J., Lewis, A.J., 1998. Complementary responses between feather meal and poultry by-product meal with or without ruminally protected methionine and lysine in growing calves. J. Anim. Sci. 76, 1970-1975.

Klemesrud, M.J., Klopfenstein, T.J., Lewis, A.J., Shain, D.H., Herold, D.W., 1997. Limiting amino acids in meat and bone and poultry by-product meals. J. Anim. Sci. 75, 3294-3300.

Knaus, W.F., Beermann, G.H., Robinson, T.F., Fox, D.G., Finnerty, K.D., 1998. Effects of dietary mixture of meat and bone meal, feather meal, blood meal, and fish meal on nitrogen utilization in finishing Holstein steers. J. Anim. Sci. 76, 1481-1487. 
Lallo, C.H.O., Garcia, G.W., 1994. Poultry by-product meal as a substitute for soybean meal in the diets of growing hair sheep lambs fed whole chopped sugarcane. Small Rumin. Res. 14, 107-114.

Li, F., Chengkui, Sh, Yu, Ch, Yang, D., 2016. Waste from livestock and poultry breeding and its potential assessment of biogas energy in rural China. J. Clean. Prod. 126, 451-460.

Licitra, G., Hernandez, T.M., Van Soest, P.J., 1996. Standardization of procedures for nitrogen fractionation of ruminant feeds. Anim. Feed Sci. Technol. 57, 347-358.

Loerch, S.C., Berger, L.L., Plegge, S.D., Fahey Jr., G.C., 1983. Digestibility and rumen escape of soybean meal, blood meal, meat and bone meal and dehydrated alfalfa nitrogen. J. Anim. Sci. 57, 1037-1047.

Meeker, D.L., Hamilton, C.R., 2006. An overview of the rendering industry. In: Essential Rendering. Meeker. National Renderers Association.

Muia, J.M.K., Tamminga, S., Mbugua, P.N., Kariuki, J.N., 2001. Effect of supplementing napier grass (Pennisetumpurpureum) with poultry litter and sunflower meal based concentrates on feed intake and rumen fermentation in Friesian steers.
Anim. Feed Sci. Technol. 92, 113-126.

NRC, 2001. Nutrient Requirements of Dairy Cattle, seventh ed. National Academy Press, Washington, DC, USA.

Ørskov, E.R., McDonald, I., 1979. The estimation of protein degradability in the rumen from incubation measurements weighted according to rate of passage. J. Agric. Res. Camb. 92, 499-503.

Rojas, O.J., Stein, H.H., 2013. Concentration of digestible and metabolizable energy and digestibility of amino acids in checken meal, poultry by-product meal hydrolyzed porcine intestines, and spent hen-soybean meal mixture, and conventional soybean meal fed to weanling pigs. J. Anim. Sci. 91, 3220-3230.

SAS, Statistical Analysis System, 2000. SAS/STAT User's Guide. Release 8.02 (Cary, NC, USA).

Yoon, Y.-M., Seung-Hwan, K., Seung-Yong, Oh, Chang-Hyun, K., 2014. Potential of anaerobic digestion for material recovery and energy production in waste biomass from a poultry slaughterhouse. Waste Manag. 43, 204-209. 